\section{Dobrovolskaya K., Kovalchuk $\mathbf{5}$.}

\title{
PROBLEMATIC ASPECTS OF TRADE MANUFACTURING CHAINS BRANDING
}

Об'єктом дослідження є брендинг у виробничо-торговельних ланщюгах. В процесі літературного аналізу авторами встановлено, що більшість науковців зосереджують увагу саме на концепиї управління ланцюгами поставок. Натомість, стан і ступінь розробленості питань щодо формування $і$ управління торговельно-виробничими ланщюгами підприємств, а також брендингу в цих ланцюгах не знайшли достатнього відображення в сучасній науковій літературі. Враховуючи важливість і необхідність розв'язання окреслених питань і проблем, автори присвятили своє дослідження цій тематиці.

В ході дослідження було сформовано авторський підхід до трактування поняття «бренд» на підставі наукового узагальнення. Отримано авторське визначення поняття «бренд», під яким автори розуміють чітко ідентифікований символ, котрий для споживача є не лише інформаџійним субліматом (та/або стійким емочійним імпульсом), але і додатковою відносно товарів-конкурентів корисністю. Це пов'язано з тим, що у ході дослідження уточнено трактування поняття «брендинг» з позиції декомпозицї виробничо-торговельного ланиюга. Запропонований у роботі підхід дозволяє враховувати взаємозв'язок $i$ взаємний вплив виробничої і торговельної діяльності та отримати синергійний ефект від застосування брендингу впродовж всього виробничо-торговельного ланцюга. Завдяки цьому під поняттям «бренд» розуміємо чітко ідентифікований символ, котрий для споживача є не лише інформаційним субліматом (та/або стійким емоційним імпульсом), але і додатковою відносно товарів-конкурентів цінністю. Це у сукупності визначає вибір споживача на користь носія цього бренду. Розуміння цього забезпечує формування додаткової вартості на кожному етапі брендингу, посилює конкурентні позиції власника бренду та вдосконалює брендинг. Наступним етапом досліджень автори визначають побудову механізму брендингу у виробничоторговельних ланщюгах. Механізм має базуватися на формуванні уніфікованих для всіх ринків $і$ виробів процесах планування, термінологічних базах, структурах даних для стратегічного аналізу, стратегічних моделей і програм.

Ключові слова: управління брендом, технологія брендинга, маркетингова діяльність підприємств, брендинг виробничо-торговельного ланщюга.

\section{Introduction}

The globalization processes and the further integration of Ukraine into the European and world space are characterized by an ever-increasing saturation of the market space of information, an increase in its significance and value. In these conditions, the processes of generating demand and customer loyalty, marketing impact on them are becoming significantly more complicated.

Consequently, the success of Ukrainian enterprises depends not only on internal performance and the ability to adapt to changes in the external environment, but also on the ability to properly gain a strong market position for the long term. This is precisely the ability of enterprises to ensure the use of branding in their activities, which allows not only to identify the company's products, but to increase the market value of the enterprise as a whole. It is also worth noting that recently the issues of implementing joint branding have become relevant, which reduces the risk of entering the market, adds the corresponding competitive advantages to enterprises that carry out joint activities. It also reduces the level of marketing costs for product promotion.

The skillful application of branding theory and practice by Ukrainian enterprises can become the key to strengthening their identification in the market, and therefore, strengthening their competitive positions and, as a result, increasing the profitability and efficiency of their functioning. As the experience of foreign countries shows, it is possible to significantly strengthen the competitive position of enterprises in the market by carrying out their activities within the framework of logistics or marketing chains.

Theoretical and methodological foundations of brand formation and management are covered in [1-3]. The formation of various chains in the field of marketing and logistics distribution is considered by the authors of works [4-6]. In the process of a detailed analysis of the work, it is found that most scientists are focused on the concept of supply chain management. But the state and degree of development of formation and management issues of trade and production 
chains of enterprises, as well as branding in these chains are not adequately reflected in modern scientific literature. The importance and necessity of solving certain questions and problems determined the choice of the research topic.

Thus, the object of research is branding in production and trade chains. And the aim of research is the theoretical and methodological justification for the use of branding in production and trade chains.

\section{Methods of research}

The author's approach to the interpretation of the concept of «brand» on the basis of scientific generalization was formed in the course of the research.

\section{Research results and discussion}

Theoretical and practical research in the field of branding, as well as directions for increasing the efficiency of enterprises through the formation of various associations and clusters, have been repeatedly covered by Ukrainian economists in their writings. However, it should be noted that only a small part of them devoted their research to defining the role of branding in the formation of the corresponding chains. And from the standpoint of assessing the role of branding in improving the effectiveness of marketing activities of production and trade chains, this issue was not covered at all in the Ukrainian scientific literature.

Considering the ambiguity of approaches to the interpretation of the concept of «brand», let's consider its most common definitions, covered by Ukrainian and foreign scientists in publications, and correlate them with the classification approaches existing and proposed by the author (Table 1). Let's characterize the approaches to classification and on the basis of scientific generalization and formulate the author's approach to the interpretation of this concept.

One of the main approaches encountered in interpreting the concept of «brand» is an identification approach, according to which a brand is considered as a means of identifying a product and establishing its difference from competitors.

Classification of approaches to the definition of the concept of «brand»

\begin{tabular}{|c|c|c|}
\hline Source & Definition & Approach \\
\hline [7] & $\begin{array}{l}\text { Brand is a combination of characteristics of a product (its attributes, perceptions and consumer knowledge } \\
\text { about a product), elements of a trademark (logo, name and sound range) and a trademark (legal protection) }\end{array}$ & Subject \\
\hline [4] & $\begin{array}{l}\text { Brand is more than advertising or marketing. This is all that comes to the person's head regarding the product } \\
\text { when it sees its logo or hears the name }\end{array}$ & Perceptual \\
\hline [8] & $\begin{array}{l}\text { Brand is an aggregate consisting of both a product that satisfies the functional needs of consumers and an added } \\
\text { value that encourages consumers to feel great joy. This satisfaction is connected with the formation of their } \\
\text { belief that this brand is of higher quality or more desirable for them than similar brands offered by competitors }\end{array}$ & Value \\
\hline [9] & $\begin{array}{l}\text { Brand is a means of highlighting a product or group of products, which allows the owner to achieve the } \\
\text { desired competitive advantage in the market }\end{array}$ & Identification \\
\hline [10] & $\begin{array}{l}\text { Brand is an exclusive concept that most people share and desire, embodied in goods, services, points of sale } \\
\text { and/or experience }\end{array}$ & Preferential \\
\hline [1] & $\begin{array}{l}\text { Brand is a set of associations that arise in the minds of consumers that add value to the product or service } \\
\text { that they perceive and create a different reaction to the brand }\end{array}$ & Perceptual \\
\hline [2] & $\begin{array}{l}\text { Brand is the seller's responsibility to provide the buyer with a specific set of product properties, benefits and } \\
\text { services, as well as quality assurance }\end{array}$ & $\begin{array}{l}\text { Based on established obliga- } \\
\text { tions of the seller to the buyer }\end{array}$ \\
\hline$[11,12]$ & $\begin{array}{l}\text { Brand is a form of presenting unique information that provides, forms and develops mutually beneficial rela- } \\
\text { tions in the market and encourages exchanges and agreements }\end{array}$ & Complex \\
\hline [13] & $\begin{array}{l}\text { Brand is a consistent set of functional, emotional, psychological and social promises to the target consumer } \\
\text { that are unique and significant to it and that best suit its needs. }\end{array}$ & $\begin{array}{l}\text { Based on the promise of the } \\
\text { seller to the buyer }\end{array}$ \\
\hline [14] & $\begin{array}{l}\text { Brand is an intangible asset of a company, which is expressed through a name, symbol, logo or their set, } \\
\text { thereby identifying producer goods for the consumer }\end{array}$ & Value oriented \\
\hline [15] & $\begin{array}{l}\text { Brand is an idea of consumers about some of the properties of a product that distinguish it from similar } \\
\text { products, determine attachment, loyalty and trust in it, which helps to create additional profit for the enterprise }\end{array}$ & $\begin{array}{l}\text { Perceptual. } \\
\text { Value oriented }\end{array}$ \\
\hline [16] & $\begin{array}{l}\text { Brand is not something that its creators are trying to convey to the consumer, but that the consumer will } \\
\text { understand from what has been proposed due to the characteristics of consumers' memory, which works on } \\
\text { the residual principle }\end{array}$ & Preferential \\
\hline$[17,18]$ & $\begin{array}{l}\text { Brand is an integral combination of a trademark and related sustainable knowledge, images and associations } \\
\text { of consumers from the target audience, increase the volume of sales of enterprise products }\end{array}$ & Functional \\
\hline [19] & $\begin{array}{l}\text { Brand must be used to influence a person in the decision-making process on the need to perform certain } \\
\text { actions when the irrational must defeat the rational. And also with the aim of forming the style of the object, } \\
\text { which should eventually turn into an image }\end{array}$ & Complex \\
\hline [20] & $\begin{array}{l}\text { Brand is a set, a system of tangible and intangible elements, reflects a certain image of a product in the } \\
\text { mind of the consumer, which is expressed in the characteristics of the product, its design, name, advertising } \\
\text { method or other features. These features differentiate the product, providing consumers with real and/or } \\
\text { virtual, rational and/or emotional benefits. }\end{array}$ & Complex \\
\hline$[21,22]$ & $\begin{array}{l}\text { Brand of an industrial enterprise is considered as a legally protected name, in relation to which, in the target } \\
\text { audience, there is a set of unique associations that enhance the consumer value of the products of the enterprise, } \\
\text { which have developed through their own experience in using products or/and various means of differentiation }\end{array}$ & $\begin{array}{l}\text { Perceptual, } \\
\text { functional }\end{array}$ \\
\hline [23] & Brand is a tool for building and maintaining consumer loyalty. & Preferential \\
\hline
\end{tabular}


According to the perception approach, a brand is considered as a set of perceptions in the consumer's imagination; according to this approach, a brand is considered as a set of stable associations that arise in the perception of consumers. These may be associations associated with the functional, emotional and symbolic benefits of brand acquisition. In the framework of this approach, one can separately consider the subject (symbolic), functional and emotional approaches [3].

Regarding the value approach, its supporters focus on the brand's ability to provide the product with additional value.

According to the preferential approach, the ability to form consumer preferences is defined here as the main function of the brand. At its core, the preferential approach is focused on the study of the psychological aspects of brand perception and therefore is more responsive to the tasks of psychological science. Its significance is studying the nature of consumer preferences and the formation of an effective system for managing them. However, this approach reveals a relationship with the long-term goals and economic results of entrepreneurial activity.

The approach, which defines the brand as the main function of the promise of the manufacturer to the consumer, considers the brand as a combination of the names of other symbols used to identify the product and the promise that is given to the buyer. It is an integral part and natural development of the concept of social and ethical marketing, reflects the principles of corporate social responsibility and provides for responsible behavior of the brand owner. A prerequisite for the implementation of brand-oriented marketing is a high level of quality of goods or services.

However, rational motives dominate the basis of assessing consumer behavior in the brand selection process, as is true for the markets for industrial goods and longterm use. Along with this, modern studies confirm the predominance of emotional factors of brand perception in the behavior of end consumers, the ability of consumers to give preference and brand commitment, despite, for example, the relative instability of product quality.

An approach that defines as the main function of a brand the formation of relations between producer and consumer. The formation and maintenance of relations between the business entity (brand) and the consumer is an integral part and natural development of the concept of marketing relationships. The main idea of this concept is that the main object of management in marketing is to establish long-term partnerships with customers and other participants in the purchase and sale process.

The value-oriented approach interprets the brand as an intangible asset of the enterprise, forms its goodwill.

The main disadvantage of the above approaches is their relative limitations. According to approaches where the brand is viewed solely from the position of the company, it is interpreted primarily as an identification system, a risk reduction tool, a branded contract (promise) or as a carrier of additional values. According to approaches where the brand is characterized from the perspective of the consumer, its content is interpreted as a holistic image in the perception of customers, as a specific relationship between it and customers.

To overcome such disagreements, some scientists began to apply an integrated approach to the interpretation of the concept of «brand».
Summarizing the research results of the essence of the concept of «brand» and despite the fact that it is proposed to track and form it for the production and trade chain, it is possible to interpret the brand as a clearly identified symbol. For the consumer, this symbol is not only informational sublimates (and/or a stable emotional impulse), but also an additional value relative to competing goods. This together determines the consumer's choice in favor of the carrier of this brand. Understanding this ensures the formation of additional value at each stage of branding, strengthens the competitive position of the brand owner and improves branding.

Despite the decomposition carried out by the author of the components of the production and trade chain, which allows taking into account not only the components of the economic activity of enterprises. But the possibility of creating in each link a chain of additional utility for the consumer, which allows to get the maximum effect for all participants in the production and trading process, is possible to give the following definition of branding. So, «Branding is a tool for implementing strategic marketing behavior of an enterprise (group of enterprises) in the market in the process of creating and managing a brand to achieve the goals of all interested participants in the production and trade chain».

\section{Conclusions}

The author's definition of the concept of «brand» is reasoned and formulated. According to this definition, the term «brand» means a clearly identified symbol, which for the consumer is not only informational sublimates (and/or a stable emotional impulse), but also an additional value relative to competing goods. This together determines the consumer's choice in favor of the carrier of this brand. Understanding this ensures the formation of additional value at each stage of branding, strengthens the competitive position of the brand owner and improves branding.

The study clarified the definition of the concept of «branding» from the perspective of the decomposition of the production and trade chain. The next stage of research should be the construction of a branding mechanism in production and trade chains. The mechanism should be based on the formation of planning processes unified for all markets and products, terminology databases, data structures for strategic analysis, strategic models and programs.

The approach proposed in this work allows one to take into account the relationship and mutual influence of production and trading activities and to obtain a synergy effect from the use of branding throughout the entire production and trade chain.

\section{References}

1. Keller, K. (2005). Strategicheskii brend-menedzhment: sozdanie, ocenka i upravlenie marochnym kapitalom. Moscow: Viliams, 719

2. Kotler, F., Keller, K. L. (2006). Marketing menedzhment. Saint Petersburg: Piter, 816.

3. Malkova, I. V. (2006). Marochnii kapital kak nematerialnii aktio kompanii. Ekonomicheskaia teoriia: istoki i perspektioy. Moscow: Ekonomicheskii f -t MGU, TEIS, 734-741.

4. D'Alessandro, D. (2002). Voiny brendov: 10 pravil sozdaniia nepobedimoi torgovoi marki. Saint Petersburg: Piter, 224.

5. Dligach, A., Pisarenko, N. (2006). Upravlenie sistemoi brendov, ili portfelnye voiny. Marketing $i$ reklama, 2 (114), 26-34. 
6. Devis, S., Dann, M. (2005). Brend-bilding. Sozdanie biznesa, raskruchivaiuschego brend. Saint Petersburg: Piter, 448.

7. Veleshchuk, S. S. (2008). Brend-menedzhment v stratehichnomu rozvytku pidpryiemstv. Kyiv, 20

8. Doil, P. (2001). Marketing, orientirovannii na stoimost. Saint Petersburg: Piter, 480.

9. Zozulov, O., Nesterova, Yu. (2008). Brend yak nematerialnyi aktyv u postindustrialnomu suspilstvi. Ekonomika Ukrainy, 3, 4-11.

10. Kapferer, Zh.- N.; Domnin, V. N. (Ed.) (2007). Brend navsegda sozdanie, razvitie, podderzhka cennosti brenda. Moscow: Vershina, 448.

11. Malynka, O. (2006). «DNK» brenda yak systema zberezhennia vidtvorennia i peredachi informatsii do spozhyvacha. Marketynh v Ukraini, 1 (35), 34-38

12. Malinka, O., Ustenko, A. (2009). Izmerenie kapitala brenda na baze DNK-podkhoda k postroeniiu brenda. Marketing $i$ reklama, 4 (152), 62-68.

13. Mamleeva, L., Perciia, V. (2006). Anatomiia brenda. BrandAid, 217.

14. Nestereva, Yu. (2006). Metody otsinky vartosti brenda. Marketynh o Ukraini, 3, 61-64.

15. Prykhodchenko, Ya. V. (2007). Formuvannia brenda pidpryiemstva $\mathrm{v}$ umovakh marketynhovoi oriientatsii. Torhivlia $i$ rynok Ukrainy, 3 (24), 284-290.

16. Pustotin, V. (2008). Brending v Ukraine: proidennye etapy i perspektivy. Marketing $i$ reklama, 10, 19-21.

17. Shtovba, O. V. (2006). Tovarnyi brendynh pidpryiemsto ta shliakhy zabezpechennia yoho efektyonosti. Khmelnytskyi, 20.
18. Shtovba, O. V. (2003). Tovarnyi brendynh pidpryiemstv ta shliakhy yoho efektyonosti. Lviv, 41.

19. Yastremska, O. M., Timonin, O. M., Timonin, K. O. (2013) Brendy promyslooykh pidpryiemsto: formuvannia ta efektyonist oykorystannia. Kharkiv: Vyd. KhNEU, 244.

20. Yatsiuk, D. V. (2008). Upravlinnia reklamnoiu diialnistiu v systemi brendynhu na rynku prodovolchykh tovariv. Kyiv, 20.

21. I vashova, N. V.; Illiashenko, S. M. (Ed.) (2011). Znachennia brendu v zabezpechenni rynkovoi pozytsii pidpryiemstv. Problemy $i$ perspektyvy rynkovo-oriientovanoho upravlinnia innovatsiinym rozvytkom. Sumy: TOV «Drukarskyi dim «Papirus», 566-587.

22. Ivashova, N. V.; Shypulina, Yu. S. (Ed.) (2012). Innovatsiina komunikatsiina polityka promyslovykh pidpryiemstv. Mekhanizm upravlinnia potentsialom innovatsiinoho rozvytku promyslovykh pidpryiemsto. Sumy: TOV «Drukarskyi dim «Papirus», 347-359.

23. Cheverton, P. (2002). Teoriia i praktika sovremennogo marketinga: Polnii nabor strategii, instrumentov i tekhnik. Moscow: FAIR-PRES, 608

Dobrovolska Kateryna, Department of Marketing and Trade Entrepreneurship, Khmelnytskyi National University, Ukraine, e-mail: sveta_marketing@ukr.net, ORCID: http://orcid.org/00000003-0418-5 $\overline{4} 71$

Kovalchuk Svitlana, Doctor of Economic Sciences, Professor, Head of Department of Marketing and Trade Entrepreneurship, Khmelnytskyi National University, Ukraine, e-mail: sveta marketing@ukr.net, ORCID: http://orcid.org/0000-0001-9535-8678 